\title{
En Kompetencestrid i Aabenraa 1751
}

\section{Af I. Mogensen}

Den 17. Novbr. 1751 døde Degn og Skolemester i Varnæs Andreas Andersen, og om Udnævnelsen af hans Efterfølger opstod der en heftig Strid mellem Amtmand v. Massow i Aabenraa og Provst Schmidt sammesteds.

Striden havde en lang Forhistorie: 12. Okt. 1736 - altsaa 15 Aar efter Inkorporationen af den fyrstelige Del af Slesvig - blev Provst Schmidt kaldet til Provst i Aabenraa. Hans første Embedshandling var at udnævne en ny Degn i Bedsted uden at forhandle med Amtmanden.') Ved hans Tiltrædelsesbesøg hos Amtmand v. Massow foreslog denne, at der i Kaldsbrevet for Degnene i Amtet skulde staa: „med Amtmandens Vidende og Billigelse“, saaledes som det var Skik i de gamle kongelige Amter (Flensborg, Haderslev). Det gik Provsten ind paa; men han hævdede senere at have taget det udtrykkelige Forbehold, at saadant ikke maatte begrænse hans Ret til at „vælge og ansætte Degnene, og at Amtmanden kun betingede sig, at Degnen, naar han var „udnævnt og kaldet“, skulde indfinde sig hos Amtmanden og forevise sit Kaldsbrev, der kun blev underskrevet af Provsten.

I 14 Aar opstod ingen Discens.') Ved Pinsetid 1751 døde saa Degnen i Varnæs, Hinrich Rieper, og efterlod sig Enke og fem

1) T. Kanc. I. A. D.

Aabenraa Provsti Skolesager 1730-1848. I. Læg 1. Nr. 6.

2) ibid. Nr. 7. 
uforsørgede Børn. Saa henvendte Præst og Menighed sig til Provsten med Anmodning om, at han vilde ansætte en Degn, som kunde forsørge Enken og Børnene. Skønt Provsten mente, at Enkens Omstændigheder ikke var de sletteste, og at hun havde velansete og bemidlede Slægtninge i Varnæs og Omegn, saa lovede han dog at bestræbe sig for at finde "ein Subjectum", som for det første havde en tilstrækkelig Dygtighed og dernæst ikke var utilbøjelig til at ægte Enken. Et saadant Subjekt fandt Provsten i sin Tjener, Jes Asmussen, der tidligere havde været Skolemester, og som sammen med sin Tjenergerning i 4-5 Aar havde undervist dennes Børn - og som nu fik forelagt det Spørgsmaal, om han efter at have raadført sig med sin Samvittighed kunde beslutte sig til at ægte Enken.

Inden imidlertid Jes Asmussen var færdig med sine Samvittighedsovervejelser, meldte Skolemesteren i Løgumkloster Andreas Andersen, sig og meddelte, at det gottorpske Overkonsistorium havde givet ham Løfte om et Embede med ikke altfor ringe Indtægt, og han forlange at faa Varnæsembedet. Uagtet Provsten gjorde ham opmærksom paa Embedets ret smaa Indtægter og paa, at Menigheden rimeligvis vilde være uvillig overfor ham, der da han allerede var gift, ikke kunde ægte Enken, insisterede han paa at faa Embedet.

Sagen blev imidlertid endnu mere kompliceret: Præsten i Varnæs, og nogle af Menigheden der havde gennem Amtssekretæren anbefalet "den Untermeister" ved Skolen i Aabenraa, Troels Sønnichsen, til Amtmanden, ja henvendte sig endog direkte til kgl. Majestæt med Bøn om, at den af Provsten valgte Jes Asmussen maatte blive „afvist“. ${ }^{3}$ ) $\mathrm{Da}$ dette Bønskrift blev forelagt Visitatorerne (Amtmand og Provst) til Betænkning, maatte „Vocationen“ (.): Kaldsbrevets Udfærdigelse) udsættes.

Imidlertid havde Degn Andersen sendt et Andragende til Overkonsistoriet ${ }^{4}$ ) om, at det maatte blive paalagt Visitatorerne

3) ibid.

4) ibid. 
at kalde ham; han anklagede heri Provsten for at ville skubbe ham til Side til Fordel for sin Tjener. Konsistoriet dekreterede ved Reskript af $1 / 7$, at Andersen skulde have Embedet. Herefter rettede Provsten sig og indstillede Andersen til kgl. Majestæts Godkendelse, medens Amtmanden i en Særbetænkning indstillede Sønnichsen. Et kgl. clementissimum ("allermildeste") decretum $^{5}$ ) af 27/8 til Visitatorerne henviste til det Andersen givne Løfte og befalede, at Kaldelsen straks skulde udfærdiges for den „efter den Provsten tilkommende Beføjelse“ af Provsten udpegede Andersen.

Da Amtssekretæren bragte Provsten dette Dekret - der altsaa var sendt til Amtmanden - medbragte han Udkast til en Vocation udstedt $i$ begge Visitatorers Navn; men Provsten vilde ikke gaa med dertil. Da han næste Dag over for Amtmanàn indtog det samme Standpunkt, blev denne meget vred, og de Ord, som undslap ham, skammer jeg mig ved at anføre" (Citat af Provstens Indberetning); men Resultatet blev, at Provsten udfærdigede Vocationen i sit Navn alene. ${ }^{6}$ )

Saa skete det altsaa hverken værre eller bedre end, at Andreas Andersen døde 7 Uger efter, 17/11 17517) og efterlod sig Enke og „et skrøbeligt Barn“ — nu var der altsaa to Enker at forsørge. Dagen efter Dødsfaldet indfandt nogle Menighedsmedlemmer fra Varnæs sig hos Provsten og bad om, at han "rigtig snart" vilde indsætte en lige saa dygtig Degn som afdøde, med hvem de i den korte Tid havde været særlig tilfredse, og samme Dag overdrog saa Provsten sin Tjener, Jes Asmussen, Embedet. Men endnu samme Dag kom Troels Sønnichsen og forlangte Embedet, og da Provsten meddelte ham, at han havde udnævnt Asmussen, meldte Sønnichsen det omgaaende til Amtmanden, der endnu samme Aften gennem sin Sekretær foreslog Provsten at vælge Sønnichsen.

5 T. Kanc. I. A. Rescripten Registratur nævnte Datum.

6) som 2)

†) ibid. 
Provsten svarede, at han havde valgt Asmussen; men da Sekretæren opfordrede ham til personligt at meddele Amtmanden dette, afslog han det, fordi han „frygtede en ny uvenlig Modtagelse“, hvorpaa'Sekretæren „forløb sig paa en meget grov og uanstændig Maade" og gik sin Vej. Den 19. Novbr. udfærdigede saa Provsten Kaldsbrevet ${ }^{8}$ ) og formanede Asmussen til saa snart som muligt at begynde Skolearbejdet i Varnæs.

Samme Dag henvendte Sønnichsen sig til Præst og Menighed i Varnæs, der atter henvendte sig direkte til Majestæten ${ }^{9}$ ) med Bøn om at faa Sønnichsen til Degn. Den 20. om Aftenen modtog Provsten gennem Amtmanden Menighedens Anmodning til Visitatorerne om at udsætte Vocationen, til Majestætens Afgørelse forelaa, og Sønnichsen, der aabenbart er vant til at benytte Albuerne, sender en Ansøgning direkte til Majestæten $^{10}$ ) med Fremhævelse af sine egne fortræffelige Egenskaber og Anførelse af talrige Attester - bl. a. fra Provst Schmidt "for hæderlig Vandel“ - samt af Md. Riepers sørgelige Stilling og Forsikring om egen Vilje og Evne til at gøre hende lykkelig.

Den 22. Novbr. sendte Provsten Amtmanden „et allerærbødigst Svar", at Vocationen var udstedt d. 19. Saa klager Amtmanden til Overkonsistoriet over Provstens egenmægtige Adfærd, og indberetter til kgl. Majestæt, at Provsten under en Straf af $100 \mathrm{Rd}$. maa beordres til at tilbagekalde den uberettige Vocation. ${ }^{11}$ )

Klagen bliver naturligvis sendt til Erklæring hos Provsten, dennes Bemærkninger til Erklæring hos Amtmanden o. s. v. Ogsaa Menighedens Andragende sendes naturligvis til Udtalelse af Visitatorerne (altsaa Amtmand og Provst), der lige saa selv-

8) ibid.

9) som 1) $\mathrm{Nr} .11$.

10) ibid. Nr. 12.

11) som 7) (2).

Overkonsistoriet i Hertugd $\varnothing$ mmet Slesvig: Kirke- og Skolesager vedr. Aabenraa og Løgumkloster Provsti 1725-1810. Nr. 7 (1 og ,5) (Selve Amtmandens Klage er fjernet). 
følgeligt ikke kan enes om en Indstilling, men sender hver sin „separatim".

I denne Stormflod af Skrivelser giver hver af Parterne sin Fremstilling af Sagen og gør sine Synspunkter gældende.

Hele Sagen bliver af Kongen forelagt Overkonsistoriet i Kiel til Betænkning, og Overkonsistorialraad, Generalsuperintendent Reuss i Rendsburg afgiver en udførlig Indstilling: ${ }^{12}$ )

Hvorvidt der tilkommer Amtmanden i Aabenraa "concurrence" ved Besættelse af Degne- og Skolemesterembeder paa Landet, kan hverken udledes af Amtmandens Præsidium i Konsistoriet eller af den ham som "visitator primarius" tilkommende Ret og lige saa lidt af, hvad der er Ret eller Sædvane i Haderslev og Flensborg Amter, men alene af Majestætens allerhøjeste Dispositum af, hvormeget af „exercitio jurium episcopalium et patronatus“, der tilkommer hver af Visitatorerne, og da der ikke foreligger nogen kgl. Forordning derom, saa kommer det an paa Skik og Sædvane i hver Amt.

Provst Schmidt har nu godtgjort, at hans Forgængere altid har valgt og kaldet Degnene paa Landet ensidigt og uden Medvirken af Amtmanden. De efter Amtmandens Ønske i Kaldsbrevet indsatte Ord: „Vorbewusst und Concens des p. t. Amtmannes" viser i al Fald, at det ikke før var Skik i Aabenraa Amt. Disse Ord kan ikke give Amtmanden Vetoret, thi det vilde være imod Provstens Bestalling, iflg. hvilken han har samme Ret som sine "antecessores"; men de maa formentlig have saa megen Betydning, at Provsten skal meddele Amtmanden, hvilken Person han er til Sinds at vælge og kalde, og anmode om hans Indvilligelse. Men da Ordenes egentlige og sande Betydning er fastsat ved en mundtlig Forhandling, saa maatte den grundige Afgørelse heraf bero paa en nærmere Undersøgelse.

Skønt det nu havde været rimeligt og bedre, hvis Provsten ved Besættelsen af Varnæs-Embedet i Forvejen havde medclelt Amtmanden det "Subject", som han vilde vælge og kalde,

19) som 2) Nr. 5 . 
og have anmodet om hans Indvilligelse, saa kan man dog paa Grund af de foreliggende Omstændigheder ikke tage ham det saa meget ilde op, at han har handlet, som han har gjort, da han vel kunde mene at handle i Overensstemmelse med sine Rettigheder og den hidtidige Sædvane, og da han ikke uden Grund kunde haabe, at Hr. Gehejmeraaden - saaledes som det ellers er sket - vilde være tilfreds, naar han meddelte ham Kaldelsen og den valgte foreviste ham sit Bestallingsbrev. At Præst og Menighed i Varnæs havde henvendt sig direkte til "Augustissimus“ ( delsen var udstedt; det maa ogsaa tale til Gunst for hans Afgørelse, hvis det er rigtigt, hvad han forsikrer, at det er en mindre Del af Menigheden, der har indsendt den nævnte „Supplique“ - hvad der billigvis maatte undersøges, for at ikke nogle urolige Hoveder i hele Menighedens Navn kunde faa Lejlighed til at sætte deres egen Vilje igennem eller $i$ al Fald volde Vidtløftigheder og Uro.

Hvis Provsten imod sin Pligt havde kaldet et udygtigt og uværdigt „Subject“, havde det været Amtmandens Pligt at indberette Sagen enten direkte til kgl. Majestæt eller til det "höchstpreisliche“ Overkonsistorium, men Provstens Valg er velbegrundet; derfor er Reuss af den uforgribelige Mening, at 1) den af Provsten udstedte Vocation bør have kgl. Autorisation, at 2) Provsten enten uden videre faar godkendt den af hans Antecessores udøvede Ret eller at 3) det bestemmes, at han i Fremtiden, før Vocationen udstedes, skal meddele Amtmanden p. t. det Subject, han vil vælge og kalde, og afvente hans Billigelse, og at Amtmanden, hvis han har tilstrækkelig Grund til ikke at godkende Valget, skal indberette Sagen enten til kgl. Majestæt eller til Overkonsistoriet og saa afvente Afgorelsen.

Skønt Amtmandens principielle Standpunkt møder nogen Forstaaelse i Overkonsistoriet, slutter dette sig til Reuss's Indstilling, og tyske Kancelli tiltræder Overkonsistoriets Indstil- 
ling $^{13}$ ), uden at det ses, at de Undersøgelser (om Provstens Forbehold og om Flertallet i Menigheden), som Reuss fandt billige, har fundet Sted.

Kgl. Majestæts Dekret af $\left.20 / 3,{ }^{14}\right)$ godkender Overkonsistoriets Indstilling dog med den under 3) anførte Eventualitet (at Provsten skal meddele Amtmanden Valget før Kaldsbrevets Udstedelse).

Saa sidder altsaa Jes Asmussen som rettelig kaldet Degn og Skolemester i Varnæs; hvorledes han har klaret Forholdet til Enken og de fem uforsørgede Børn, melder Archivalia intet om. Sønnichsen skal - med sine gode Albuer - nok snart skaffe sig et Embede. Den eneste, som ingen har taget sig af, er Degn Andersens Enke med hendes skrøbelige Barn.

Hun sender kgl. Majestæt et Bønskrift ${ }^{15}$ ) om Hjælp, der i sin sproglige Ubehjælpsomhed er et talende Vidnesbyrd om det urimelige $i$, at danske Undersaatter maa henvende sig til Landets Monark paa Tysk. Paa dette Bonskrift foreligger der i Archivalierne intet Svar, og der foreligger intet om hendes senere Skæbne.

13) ibid. Nr. 2.

14) som 11) (2).

15) som ${ }^{1}$ ) $\mathrm{Nr} .10$. 
